\title{
Complex assessment of urban housing energy sustainability
}

\author{
Olga Popova $^{1, *}$, Julia Glebova ${ }^{1}$, and Irina Karakozova ${ }^{2}$ \\ ${ }^{1}$ Northern (Arctic) Federal University, 163000 Arkhangelsk, Russia \\ ${ }^{2}$ Moscow State University of Civil Engineering, Yaroslavskoe shosse, 26, Moscow, 129337, Russia
}

\begin{abstract}
The article presents the results of a complex experimentalanalytical research of residential development energy parameters - survey of construction sites and determination of calculated energy parameters (resistance to heat transfer) considering their technical condition. The authors suggest a methodology for assessing residential development energy parameters on the basis of construction project's structural analysis with the use of advanced intelligent collection systems, processing (self-organizing maps - SOM) and data visualization (geo-informational systems - GIS). SOM clustering permitted to divide the housing stock (on the example of Arkhangelsk city) into groups with similar technical-operational and energy parameters. It is also possible to measure energy parameters of construction project of each cluster by comparing them with reference (normative) measures and also with each other. The authors propose mechanisms for increasing the area's energy stability level by implementing a set of reproduction activities for residential development of various groups. The analysis showed that modern multilevel and high-rise construction buildings have the least heat losses. At present, however, ow-rise wood buildings is the dominant styles of buildings of Arkhangelsk city. Data visualisation on the created heat map showed that such housing stock covers the largest urban area. The development strategies for depressed areas is in a high-rise building, which show the economic, social and environmental benefits of upward growth of the city. An urban regeneration programme for severely rundown urban housing estates is in a high-rise construction building, which show the economic, social and environmental benefits of upward growth of the city.
\end{abstract}

\section{Introduction}

A large number of scientific researches on the issues of resource conservation are related to construction technology, studies of the material energy characteristics products and structures [1-5], research of separate construction projects and utilities energy parameters. In its order urbanized areas are a complex system of interrelated elements and presume the need for a comprehensive study of the energy systems parameters.

\footnotetext{
* Corresponding author: oly-popova@yandex.ru
} 


\section{Materials and methods}

The research carried out by the authors has made it possible to identify and clarify the complex characteristics of the urbanized development area energy system. The set of energy security and energy intensity parameters along with the dynamic indexes of energy efficiency of all area energy system components determines its integrated assessment - the energy sustainability of the area.

Energy parameters of development are an important component of the area energy sustainability in general since it is one of the main consumers of energy resources.

The methodology for assessing the energy parameters of the development area represents itself the detection of the energy parameters list (formation of factor space), complex assessment of construction project by selected parameters, determination of mechanisms for increasing the level of area's energy sustainability. The methodology includes:

1. Experimental-analytical research of urban development energy parameters.

Experimental-analytical research of energy parameters lays in the examining of existing developments (definition of designation, technical-operational, energy parameters and other characteristics of construction projects) and forecasting of its complex reproduction (new construction, capital repairs, modernization, etc.).

Technical-operational and energy parameters of the existing development are characterized by the number and structure of consumers (construction projects), constructive solutions, technical condition, the level of obsolescence.

The possibility for new construction depends on the capacities of existing energy sources or alternative ones (the technical access to utilities, engineering communications, the availability of free heating energy). The possibility of reproduction activities for existing development (capital repairs, modernization, etc.) is mainly determined by technological capabilities and economic efficiency of projects.

The result of the first stage is the formation of the factor space and database.

2. Structural analysis of urban development area's energy parameters via clustering with the use of self-organizing maps (SOM).

The created datebase, which includes multidimensional data of the development projects' characteristics, serves as a basis for structural analysis with the usage of Deductor Studio Academic software product, the platform - Kohonen's self-organizing maps (SOM). Buildings and constructions of different designation are grouped by the highest similarity of chosen characteristics. The resulting groups of projects (clusters) have a high level of characteristic similarity within one group.

3. Designing the strategy for increasing the level of development energy sustainability for each group of projects.

Each group of projects can be described by the group average parameter values. After that, a development strategy for projects of each group is formed including the required list and amount of reproductive activities for increasing the energy sustainability of buildings considering the amount and efficiency of capital investments.

4. Data visualization using geo-informational systems (GIS)

The urban development projects under investigation are displayed on a geo-informational map. Data visualization by means of GIS (Software product QGIS 2.18) allows one to present the urbanized development projects with their description and geo-referencing. The opportunity of forming thematic heat cards gives a chance to assess the overall state of an area's energy sustainability. 


\section{Experiment}

The housing stock of the city has a long history of formation and represents a set of construction projects for individual and commercial developments of different periods. Each period is characterized by features of technology, materials, design and construction norms. By the current moment of time, each urban development has formed its specific identity. This is expressed in a single factor space for any area (the same list of characteristics), but in a different values of those factors for each area in particular.

The authors carried out the research of residential development energy parameters on the example of the Arkhangelsk city. It is one of the largest seaports in the North-West of Russia. The climate is maritime subarctic with long winters and short cool summers. Climatic features of the territory determine the design and energy characteristics of the development.

The main part of the city's residential development was formed in the periods from 19001950 and 1950-1980. It is currently presented by wooden individual houses and barrackstype houses, brick and panel buildings of typical development, buildings of large-panel housing construction. This type of development is typical for most of the existing urbanized areas of the Arctic zone.

\subsection{Experimental-analytical research of residential development energy parameters}

As a result of the research the authors have formed a data array containing up-to-date information on the residential development characteristics in the number of 2196 units located in the central part of the city.

Energy parameters of residential development are determined by the most essential elements of comparison:

1. Characteristics of the existing housing stock:

- special arrangements (type, house series, number of storeys, total building area);

- the design resistance to heat transfer of the building's main cladding is determined by the calculation method on the basis of typical design decisions considering materials used in the construction. General characteristics of the housing stock of different construction periods are structured and presented in the Table 1;

- year of construction;

- technical condition (level of physical deterioration);

- moral obsolescence (availability of in-house engineering communications - heat and water supply, water disposal, electrification).

2. Characteristics of the new construction area:

- availability of development free allotments or already built-up ones that requires renovation through demolition and new construction;

- availability of free energy capacities, which is determined by the possibility of connecting new construction projects to supporting utilities. This research uses the values of the heat load increase (Gcal / h) for the period from 2018-2027 and the load level of power centers by city districts.

\subsection{SOM clustering of residential development projects}

The clustering made it possible to identify homogeneous groups of projects with a high similarity in the technical-operational and energy characteristics within the same group shown in Table 2. 
As a result of the research, it was revealed that the main part of capital construction projects does not meet the requirem of energy efficiency being in unsatisfactory technical condition with signs of obsolescence.

The design resistance to heat transfer of the residential development cladding in the central part of the Arkhangelsk is $\mathrm{R} 0 \mathrm{sd}=1,79 \mathrm{~m}^{2} \times{ }^{\circ} \mathrm{C} / \mathrm{W}$, which is twice lower than the normative value $\left(\right.$ Rreq $\left.=3,54 \mathrm{~m}^{2} \times{ }^{\circ} \mathrm{C} / \mathrm{W}\right)$.

Table 1. Enlarged structuring of housing stock in Arkhangelsk.

\begin{tabular}{|c|c|c|c|c|c|}
\hline $\begin{array}{l}\text { Con- } \\
\text { struc- } \\
\text { tion } \\
\text { year }\end{array}$ & $\begin{array}{l}\text { Series, type of } \\
\text { house }\end{array}$ & Wall Material & $\begin{array}{c}\mathbf{R}_{0 \mathrm{sd}}, \\
\mathbf{m}^{2} \times{ }^{\circ} \mathrm{C} / \mathrm{W}[25]\end{array}$ & $\begin{array}{c}\text { Technical } \\
\text { condition [27] } \\
\text { (physical } \\
\text { deterioration), } \\
\% \\
\end{array}$ & Obsolescence \\
\hline $\begin{array}{c}1930- \\
1960\end{array}$ & $\begin{array}{c}\text { Wooden } \\
\text { multidwelling } \\
\text { houses ( } 2 \text { and } 3 \\
\text { blocks) }\end{array}$ & $\begin{array}{l}\text { Wood, beam } \\
150 * 150 \mathrm{~mm} \text {. }\end{array}$ & 1,43 & $\begin{array}{l}\text { Unsatisfactory - } \\
45-60 \% ; \\
\text { Dilapidated - 61- } \\
80 \%\end{array}$ & $\begin{array}{c}\text { Basically, the lack of } \\
\text { connection to one or more of } \\
\text { the city's utilities(central } \\
\text { heating, water supply, water } \\
\text { disposal) }\end{array}$ \\
\hline $\begin{array}{l}1950- \\
1960\end{array}$ & $\begin{array}{l}\text { Construction } \\
\text { projects of the } \\
\text { postwar } \\
\text { development }\end{array}$ & $\begin{array}{c}\text { Ceramic brick with } \\
\text { a thickness of } 2- \\
2.5 \text { bricks }\end{array}$ & 0,91 & $\begin{array}{c}\text { Unsatisfactory - } \\
45-55 \%\end{array}$ & Not found \\
\hline $\begin{array}{l}1958- \\
1965\end{array}$ & $\begin{array}{l}\text { Typical } \\
\text { residential } \\
\text { buildings of } \\
\text { 1-464A series }\end{array}$ & $\begin{array}{l}\text { Single-layer } \\
\text { expanded-clay } \\
\text { concrete panels }\end{array}$ & 0,77 & $\begin{array}{c}\text { Unsatisfactory - } \\
41-50 \%\end{array}$ & $\begin{array}{c}\text { small kitchen areas } \\
(4-6 \mathrm{~m} 2) \text {; connected sanitation } \\
\text { units; incapability of capital } \\
\text { redesign; low sound insulation }\end{array}$ \\
\hline $\begin{array}{c}1960- \\
1970\end{array}$ & $\begin{array}{l}\text { Typical } \\
\text { residential } \\
\text { buildings of } \\
1-335 \text { series }\end{array}$ & $\begin{array}{c}\text { Double-layer } \\
\text { reinforced concrete } \\
\text { panels }\end{array}$ & 0,43 & $\begin{array}{c}\text { Unsatisfactory - } \\
41-50 \%\end{array}$ & $\begin{array}{l}\text { small kitchen areas } \\
\text { (4-6 m2); low ceilings; narrow } \\
\text { corridors and small staircases; } \\
\text { connected sanitation units; } \\
\text { incapability of capital } \\
\text { redesign; low sound insulation }\end{array}$ \\
\hline $\begin{array}{l}1965- \\
1975\end{array}$ & $\begin{array}{l}\text { Typical } \\
\text { residential } \\
\text { buildings of } \\
\text { 1-335-AK-11 } \\
\text { series } \\
\end{array}$ & $\begin{array}{c}\text { Double-layer } \\
\text { reinforced concrete } \\
\text { panels }\end{array}$ & 0,43 & \begin{tabular}{|} 
Satisfactory - 35- \\
$40 \%$ \\
Unsatisfactory - \\
$41-45 \%$
\end{tabular} & $\begin{array}{c}\text { small kitchen areas } \\
(4-6 \mathrm{~m} 2) \text {; incapability of } \\
\text { capital redesign; low sound } \\
\text { insulation }\end{array}$ \\
\hline $\begin{array}{l}1960- \\
1980\end{array}$ & $\begin{array}{c}\text { Typical } \\
\text { residential } \\
\text { buildings of } \\
1-447 ; 1-447 \mathrm{C}- \\
47 ; 1-447 \mathrm{C}-48 \\
\text { series } \\
\end{array}$ & $\begin{array}{c}\text { Calcium silicate } \\
\text { brick with a } \\
\text { thickness of } 2-2.5 \\
\text { bricks }\end{array}$ & 0,68 & \begin{tabular}{|} 
Satisfactory - 35- \\
$40 \%$ \\
Unsatisfactory - \\
$41-45 \%$
\end{tabular} & $\begin{array}{l}\text { small kitchen areas } \\
\qquad(4-6 \mathrm{~m} 2)\end{array}$ \\
\hline $\begin{array}{c}1985- \\
1998\end{array}$ & \begin{tabular}{|c} 
Typical \\
residential \\
buildings of 111- \\
93 series \\
\end{tabular} & $\begin{array}{l}\text { Three-layer } \\
\text { Reinforced } \\
\text { concrete panels }\end{array}$ & 3,55 & $\begin{array}{c}\text { Satisfactory }-31- \\
40 \%\end{array}$ & Not found \\
\hline $\begin{array}{l}\text { since } \\
1990\end{array}$ & $\begin{array}{c}\text { Individual } \\
\text { cottage houses }\end{array}$ & $\begin{array}{l}\text { Wooden, mixed } \\
\text { construction with } \\
\text { the use of energy- } \\
\text { efficient insulation }\end{array}$ & 4,06 & $\begin{array}{c}\text { Good - up to } \\
20 \% \text {; Satisfactory } \\
-31-35 \%\end{array}$ & Not found \\
\hline $\begin{array}{l}\text { since } \\
2000\end{array}$ & $\begin{array}{l}\text { Typical } \\
\text { residential } \\
\text { buildings of } 93 \\
\text { series with } \\
\text { improved } \\
\text { cladding } \\
\end{array}$ & $\begin{array}{c}\text { Reinforced } \\
\text { concrete panels, } \\
\text { effective } \\
\text { insulation, facing } \\
\text { brick }\end{array}$ & 3,56 & $\begin{array}{c}\text { Good - up to } \\
20 \% \\
\text { Satisfactory - } 31- \\
35 \%\end{array}$ & Not found \\
\hline $\begin{array}{c}\text { Since } \\
1990\end{array}$ & $\begin{array}{c}\text { Residential } \\
\text { buildings with } \\
\text { individual } \\
\text { planning } \\
\end{array}$ & \begin{tabular}{|} 
Ceramic brick with \\
a thickness of 2 - \\
2.5 bricks, \\
effective insulation
\end{tabular} & 4,33 & $\begin{array}{c}\text { Good - up to } \\
20 \%\end{array}$ & Not found \\
\hline
\end{tabular}


Table 2. Clustering of housing stock in the central part of Arkhangelsk.

\begin{tabular}{|c|c|c|c|c|c|c|c|c|}
\hline $\begin{array}{l}\mathrm{N} \text { of } \\
\text { clu- } \\
\text { ster }\end{array}$ & $\begin{array}{c}\text { Ener-gy } \\
\text { facili- } \\
\text { ties }\end{array}$ & $\begin{array}{c}\text { Con- } \\
\text { struc- } \\
\text { tion } \\
\text { year }\end{array}$ & $\begin{array}{c}\text { Material of enclosing } \\
\text { structures, project } \\
\text { type }\end{array}$ & \begin{tabular}{|c|} 
Technical \\
condition \\
(physical \\
deterioration) \\
{$[27]$} \\
\end{tabular} & Utilities & $\begin{array}{c}\mathbf{R}_{0}{ }^{\mathrm{d} \text { av }} \\
\mathbf{m}^{2} \times{ }^{\circ} \mathbf{C} / \mathbf{W}\end{array}$ & $\begin{array}{l}\text { Comp- } \\
\text { liance } \\
\text { with } \\
\text { regula- } \\
\text { tions }\end{array}$ & $\begin{array}{c}\text { Energy } \\
\text { capacities }\end{array}$ \\
\hline 0 & 29 & $\begin{array}{l}1995- \\
2015\end{array}$ & $\begin{array}{c}\text { wood, effective } \\
\text { thermal insulation - } \\
\text { individual residential } \\
\text { houses }\end{array}$ & $\begin{array}{l}\text { good and } \\
\text { satisfactory } \\
(10-35 \%)\end{array}$ & partly & 4,2 & Yes & sufficiently \\
\hline 1 & 151 & $\begin{array}{l}1980- \\
2014\end{array}$ & $\begin{array}{c}\text { brick with heat- } \\
\text { insulating materials, } \\
\text { large-panel buildings, } \\
\text { multilevel and high- } \\
\text { rise construction } \\
\text { buildings }\end{array}$ & $\begin{array}{l}\text { good and } \\
\text { satisfactory } \\
(20-40 \%)\end{array}$ & fully & 4,07 & Yes & sufficiently \\
\hline 2 & 138 & $\begin{array}{l}1960- \\
2014\end{array}$ & $\begin{array}{l}\text { brick with heat- } \\
\text { insulating materials, } \\
\text { large-panel building, } \\
\text { multilevel and high- } \\
\text { rise construction } \\
\text { buildings }\end{array}$ & $\begin{array}{l}\text { good and } \\
\text { satisfactory } \\
(20-40 \%)\end{array}$ & fully & 4,04 & Yes & limited \\
\hline 3 & 198 & $\begin{array}{l}1940- \\
1995\end{array}$ & $\begin{array}{l}\text { silicate brick - } \\
\text { massive series; } \\
\text { ceramic brick- } \\
\text { postwar period, } \\
\text { reinforced concrete - } \\
\text { panel of the Soviet } \\
\text { period }\end{array}$ & $\begin{array}{l}\text { satisfactory, } \\
\text { unsatisfactory } \\
(30-65 \%)\end{array}$ & fully & 0,61 & No & sufficiently \\
\hline 4 & 307 & $\begin{array}{l}1920- \\
1985\end{array}$ & $\begin{array}{l}\text { ceramic brick - } \\
\text { postwar period, } \\
\text { reinforced concrete - } \\
\text { panel of the Soviet } \\
\text { period }\end{array}$ & $\begin{array}{c}\text { satisfactory, } \\
\text { unsatisfactory } \\
(30-65 \%)\end{array}$ & fully & 0,64 & No & limited \\
\hline 5 & 626 & $\begin{array}{l}1900- \\
1980\end{array}$ & $\begin{array}{c}\text { Wood, 2-3 block } \\
\text { multi-dwelling } \\
\text { apartments of barrack } \\
\text { type, individual } \\
\text { houses }\end{array}$ & $\begin{array}{l}\text { satisfactory, } \\
\text { unsatisfactory, } \\
\text { dilapidated } \\
\text { (40-90\%); } \\
\text { partly with } \\
\text { overhauling }\end{array}$ & $\begin{array}{c}\text { partly } \\
\text { (electrificat } \\
\text { ion) }\end{array}$ & 1,43 & No & sufficiently \\
\hline 6 & 747 & $\begin{array}{c}1900- \\
1980\end{array}$ & $\begin{array}{c}\text { Wood, 2-3 block } \\
\text { multi-dwelling } \\
\text { apartments of barrack } \\
\text { type, individual } \\
\text { houses }\end{array}$ & \begin{tabular}{|c|} 
satisfactory, \\
unsatisfactory, \\
dilapidated \\
$(40-90 \%) ;$ \\
partly with \\
overhauling
\end{tabular} & $\begin{array}{c}\text { partly } \\
\text { (electrificat } \\
\text { ion) }\end{array}$ & 1,43 & No & limited \\
\hline
\end{tabular}

\subsection{Designing the strategy for increasing the level of development energy- resistance for each group of construction projects}

Comparative characteristics' analysis of the project groups with reference values (normative) and with each other allows one to define common development strategies for groups including a list of possible reproductive activities shown in Table 3. 
Table 3. Housing stock of cluster characteristics in the central part of Arkhangelsk.

\begin{tabular}{|c|l|}
\hline $\begin{array}{c}\text { Cluster's } \\
\mathbf{N}\end{array}$ & \multicolumn{1}{|c|}{$\begin{array}{c}\text { Characteristics of the cluster / Description of recommended reproduction } \\
\text { activities }\end{array}$} \\
\hline 0 & $\begin{array}{l}\text { Construction projects with heat losses complies with standards, in good condition } \\
\text { suitable for further operation: } \\
- \text { fulfilment of current and capital repairs according the normative periods of its } \\
\text { conduction; } \\
- \text { modernization of existing utilities (full complex of utilities improvement for } \\
\text { residential development); } \\
- \text { new construction on the development free allotments with free energy capacities } \\
\text { (cluster 0 and 1) }\end{array}$ \\
\hline 1 & $\begin{array}{l}\text { Construction projects with the largest heat losses, in good condition suitable for } \\
\text { further operation: } \\
- \text { conduction of current and capital repairs with increasing resistance to the heat } \\
\text { transfer of the enclosing structures (external walls, floor, coverage, window and door } \\
\text { openings) - energy-efficient repairs; } \\
\text { - repair and / or replacement of in-house sanitary equipment; } \\
- \text { new construction on the development free allotments with free energy capacities } \\
\text { (cluster 3). }\end{array}$ \\
\hline 4 & $\begin{array}{l}\text { Construction projects with high heat losses in unsatisfactory condition: } \\
- \text { No economic effect from energy-efficient repairs - conduction of reproductive } \\
\text { activities with a supporting character until demolition; } \\
- \text { Demolition, new construction considering the financial costs of the planning period } \\
\text { and the availability of energy capacities (cluster 5); } \\
- \text { modernization of existing utilities; } \\
- \text { creation of the new available energy capacities for renovation of the development }\end{array}$ \\
\hline 5
\end{tabular}

\subsection{Data visualization using GIS}

Urban development projects forming a cluster with a certain set of energy parameters characteristics are displayed on a geo-information basis - a map (Fig. 1). The created heat map displays design reduced resistance to heat transfer of constriction project walls in the central part of the Arkhangelsk. Gradient red marked projects have below the normative value of the parameter. Gradient blue marked projects have above the normative value of the parameter.

As a result of the research, it was revealed that the main part of capital construction projects does not meet the requirements of energy efficiency. The cluster analysis data shows that such projects belong to clusters 3-6. Those are projects in satisfactory, unsatisfactory, dilapidated and emergency condition and requiring different amount of reproduction activities up to capital repairs, modernization, demolition and new construction. The total project capacity of 3-6 cluster is 1878 pc., which is $85 \%$ of the existing residential development.

At the moment, in view of the available financial resources for clusters 3,4 - brick and panel construction of post-war and Soviet periods ( $22 \%$ of the residential development in the central part of the city) - it would be mostly productive to carry out a complex of energyefficient repairs aimed at reducing the consumption of resources considering possible construction technologies, the amount and efficiency of capital investments. The technical condition of the projects (the average physical deterioration - 30-65\%) will allow them to operate until the next inter-repair period.

Projects of clusters 5,6 - wooden 2-3 blocks multi-dwelling barrack type houses and individual houses partially equipped with utilities $(63 \%$ of residential development in the central part of the city) - do not meet the heat engineering standards, while in unsatisfactory and dilapidated condition, not suitable for further operation. Demolition and new 
construction are seen more cost-effective and investment-attractive. An urban regeneration programme for severely rundown urban housing estates is in a high-rise construction building, which show the economic, social and environmental benefits of upward growth of the city.

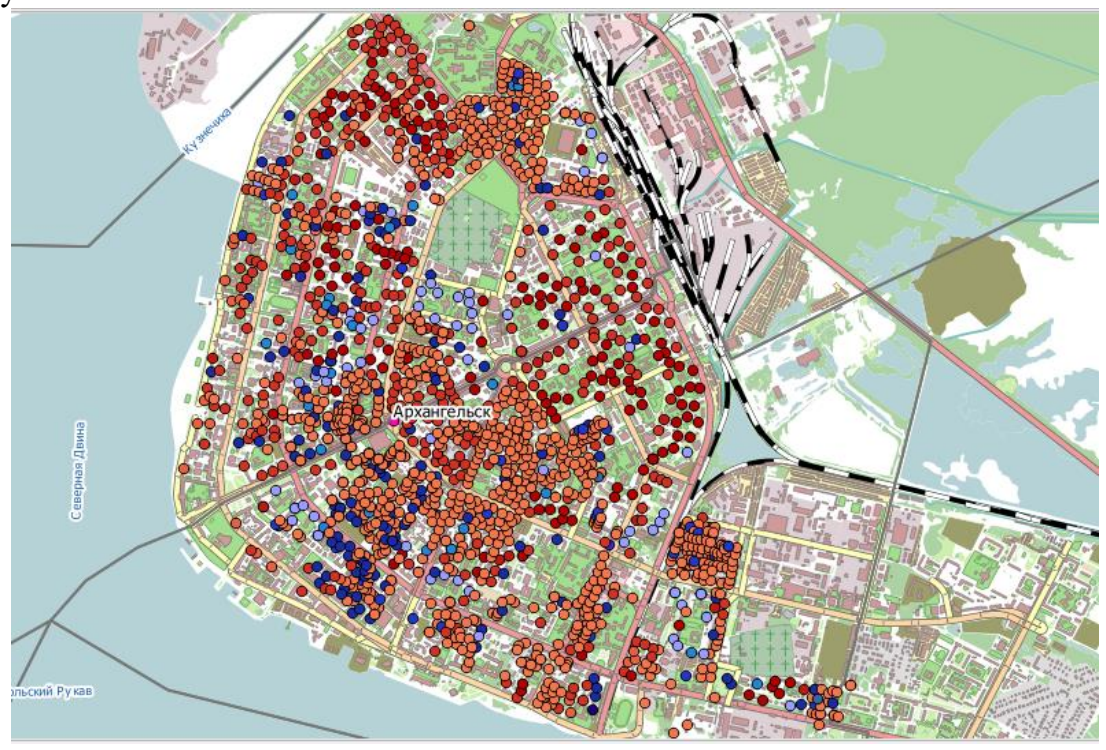

Fig. 1. Heat Map - clustering of housing stock in the central part of the Arkhangelsk by energy parameters.

\section{Results}

As the main component of the city's built-up area housing stock characteristics lead to a conclusion about the high energy capacity of the city territory.

Clustering of residential development by energy parameters allows us to identify groups of construction projects requiring updating and propose a typal list and scope of reproduction activities for each group. On the basis of the proposed strategies it is possible to develop targeted development programs for individual areas (for example quarters) taking into consideration the characteristics of the formed residential development aggregate. Targeted programs should be developed in light of detailed project surveys (visual, instrumental) and regulatory requirements of operation along with possible dynamics of residential development wear. Construction and installation work plan will reduce its terms and cost.

The development strategy for each cluster assumes the implementation of reproductive activities to increase the energy-resistance of buildings, improvement of urban area and financing mechanisms for investment-construction projects.

Periodic study of the development energy parameters and changes in the heat map of the project characteristics will give an opportunity not only to monitor the indexes of energy sustainability, but visualize them on the geo-basis and assess the transformations in the city's energy system with reference to the particular area.

\section{Conclusions}

The proposed methodology is unified for any type of development and can be adapted for implementing on any territory. Such approach considers not only the required reduction of energy consumption for individual projects, but also a comprehensive study, an assessment 
of the city's energy system, long-term reproduction and utilities planning (including new construction, reconstruction, modernization, capital and current repairs) in municipalities and regions.

\section{References}

1. A.N. Belous, et al Construction of Unique Buildings and Structures 11 (50) (2016) (doi: 10.18720/CUBS.50.1)

2. A.I. Kopylova, et al Construction of Unique Buildings and Structures 10 (49) (2016)

3. S.V Korniyenko, et. Al. Construction of Unique Buildings and Structures 6 (45) (2016)

4. H. U. Rehman. Experimental performance evaluation of solid concrete and dry insulation materials for passive buildings in hot and humid climatic conditions. Applied Energy 185 (2017) (doi: 10.1016/j.apenergy.2016.01.026).

5. S.Yu. Tarabukina, T.L. Simankina, et. Al. Construction of Unique Buildings and Structures 3 (54) (2017) (doi: 10.18720/CUBS.54.4). 